\author{
Krystian Sowislok \\ II Liceum Ogólnokształcące \\ w Zabrzu
}

\title{
Proces globalizacji. Ocena pozytywnych i negatywnych skutków globalizacji przez młodych Polaków
}

Czym jest globalizacja? Co to pojęcie oznacza dla młodych ludzi? Czy słownikowe wyjaśnienia tego pojęcia są dla nich zrozumiałe, a informacje podręcznikowe na ten temat - wystarczające i precyzyjne? Czy wiedzą, jakie są pozytywne oraz czy dostrzegają także negatywne skutki globalizacji w Polsce i na świecie? Jak mogą wspierać, a może przeciwdziałać temu procesowi? Takie i podobne pytania związane z globalizacją zadałem uczniom klas drugich i trzecich liceum ogólnokształcącego. Zawsze podkreślam, że jako nauczyciela przedmiotu podstawy przedsiębiorczości najbardziej interesują mnie opinie i postawy młodzieży. Biorąc jednak pod uwagę młody wiek ankietowanych, uznałem, że formułowanie pytań bezpośrednio związanych z tytułem tegorocznej konferencji i zjazdu nauczycieli, czyli przedsiębiorczością w warunkach globalizacji, byłoby przedwczesne.

Procesy globalizacji są jednym z tematów (ostatnim) w podręczniku Podstawy przedsiębiorczości dla uczniów szkót ponadgimnazjalnych wydawnictwa Nowa Era. Ze względu na ogromne znaczenie tych procesów i ich wpływ na nasze codzienne życie i rozwój Polski, ten temat, wraz z całym rozdziałem Wspótpraca międzynarodowa omawiam jednak wcześniej. Staram się przekazywane wiadomości rozszerzyć, również z udziałem uczniów, o dostępne w Internecie i literaturze materiały.

Aby przybliżyć skutki globalizacji, trzeba oczywiście rozpocząć od przedstawienia powszechnie przyjętych definicji tego pojecia. Oprócz encyklopedycznych, nie zawsze łatwych do zrozumienia dla młodzieży, przedstawiam im wyjaśnienie sformułowane przez humanistę Richarda Schechnera (badacz, teoretyk, reżyser i krytyk teatralny, profesor performatyki na Uniwersytecie w Nowym Yorku) w książce Performatyka: Wstęp. Można tam przeczytać, że „Zadaniem naczelnym globalizacji jest integracja wszystkich systemów - informacyjnych, gospodarczych, wojskowych, ideologicznych, społecznych, politycznych i kulturalnych - wedle zasady high performance (wysokiej klasy; dużej wydajności.), czyli w tym przypadku: wysokiej wydajności. Jeżeli się to powiedzie, powstanie światowa sieć maksymalnej produktywności" (2007). Okazuje się, że to wyjaśnienie jest bardzo dobrze odbierane i, co najważniejsze, w pełni zrozumiałe dla młodzieży. Opierając się na przytoczonych wyżej słowach Schechnera, sformułowałem pierwsze pytanie w ankiecie przygotowanej dla uczniów szkoły, w której pracuję. Dotyczyło ono obszarów, na które ich zdaniem globalizacja ma największy wpływ. Mieli je ponumerować od 1 do 6 , według posiadanej wiedzy i indywidualnych poglądów.

Zdaniem większości uczniów, procesy globalizacji najbardziej są odczuwane w sferze gospodarczej. Na pierwszym miejscu umieściło ją $62 \%$ ankietowanych, systemy informacyjne $-20 \%$, społeczne - 10\% (ryc. 1). Nieco inna kolejność jest w wypadku podsumowania wyników 
zaznaczonych odpowiedzi na trzech kolejnych miejscach (1-3). Systemy gospodarcze i w tym wypadku były wybierane najczęściej - przez $88 \%$ badanych, następnie: społeczne - 71\% i informacyjne $-50 \%$ (ryc. 2).

Wybory młodzieży nie są zaskoczeniem. Kiedy młodzi ludzie słyszą informacje o globalizacji, w większości są one związane z gospodarką. Żyją w czasach ciągłych zmian, w tym również społecznych, stąd i ten obszar był przez nich często wybierany. Wydaje się, że trochę inaczej jest z systemami informacyjnymi. Starsze pokolenia odczuwają w tej dziedzinie olbrzymi krok naprzód, dla młodzieży jest to coś zupełnie normalnego, co towarzyszy im w codziennym życiu. Nie dziwi rzadszy wybór systemów politycznych i wojskowych, gdyż tymi obszarami młodzi ludzie niewiele się na razie interesują.

Ryc. 1. Najczęściej zaznaczane na pierwszym miejscu przez uczniów II LO w Zabrzu obszary wpływu procesu globalizacji
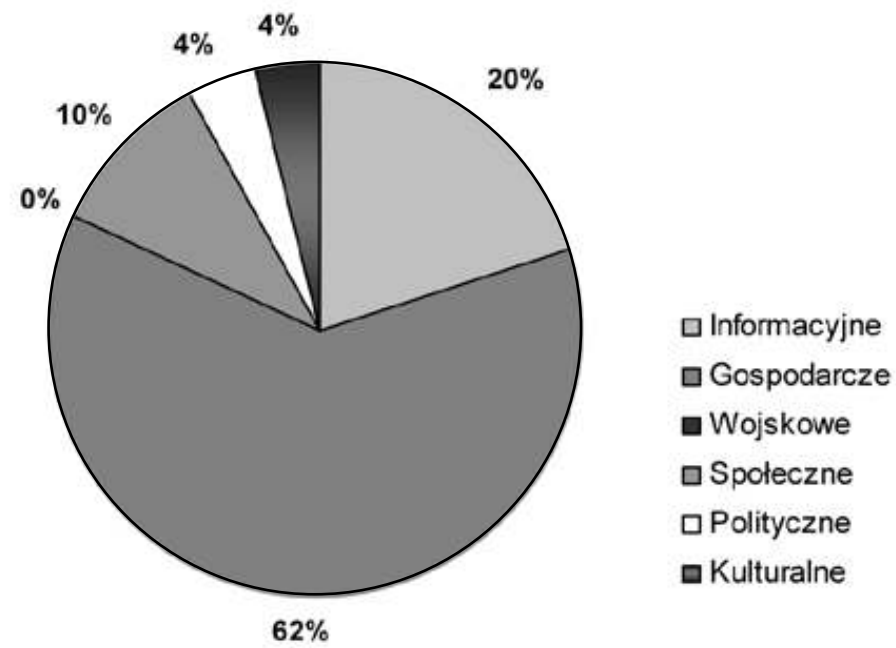

Źródło: opracowanie własne.

Ryc. 2. Najczęściej zaznaczane na miejscach 1-3 przez uczniów II LO w Zabrzu obszary wpływu procesu globalizacji

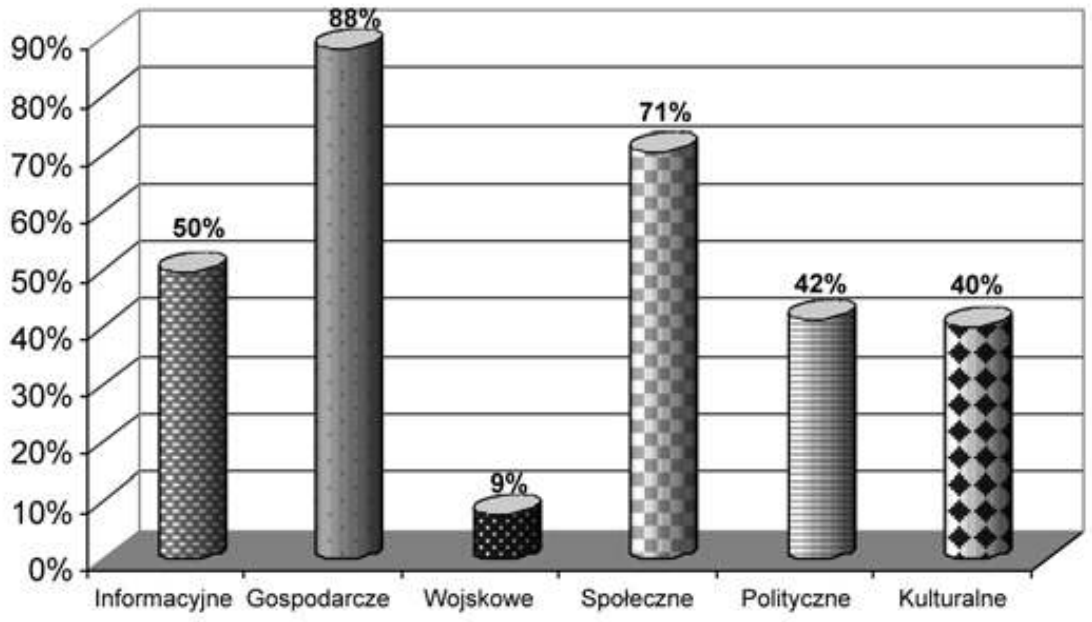

Źródło: opracowanie własne.

Globalizacja powoduje nieustanne zmiany. Ogromną rolę w zachodzących procesach odgrywają korporacje transnarodowe, które stale poszerzają zakres swojej działalności. „Ich znaczenie będzie wzrastać dzięki rosnącej finansowej sile, coraz większym możliwościom 
wpływu na narodowe państwa i na globalną gospodarkę. Z tego też powodu należy nieustannie obserwować ich dalszy rozwój, ponieważ może się ziścić scenariusz wielu ekonomistów, którzy oczekują na znaczny spadek roli państwa na rzecz korporacji transnarodowych oraz innych pozapaństwowych podmiotów procesu globalizacji” (Kolka 2007). Mówiąc o roli korporacji transnarodowych, istotne wydaje się określenie, czym zajmują się największe z nich. Na pytanie o to, z jakimi rodzajami działalności kojarzą się największe korporacje transnarodowe, uczniowie odpowiadali w drugim punkcie ankiety. Najczęściej wskazywany był przemysł surowcowy związany przede wszystkim z wydobyciem i przetwarzaniem ropy naftowej. Tak zaznaczyło 59\% badanych. Kolejne miejsca to elektronika - 19\% i motoryzacja - 12\% (ryc. 3). Rozpatrując wskazania uczniów pod względem miejsc 1-3, ze względu na dużą liczbę wskazań na drugim i trzecim miejscu branży motoryzacyjnej kolejność się zmieniła: na pierwszym miejscu znalazł się przemysł surowcowy $(76 \%)$, na drugim - motoryzacja $(67 \%)$, a na trzecim - elektronika (62\%; ryc. 4).

Ryc. 3. Największe aktywa wśród światowych korporacji transnarodowych posiadają według uczniów II LO w Zabrzu przedsiębiorstwa branży (najczęściej zaznaczane na pierwszym miejscu)

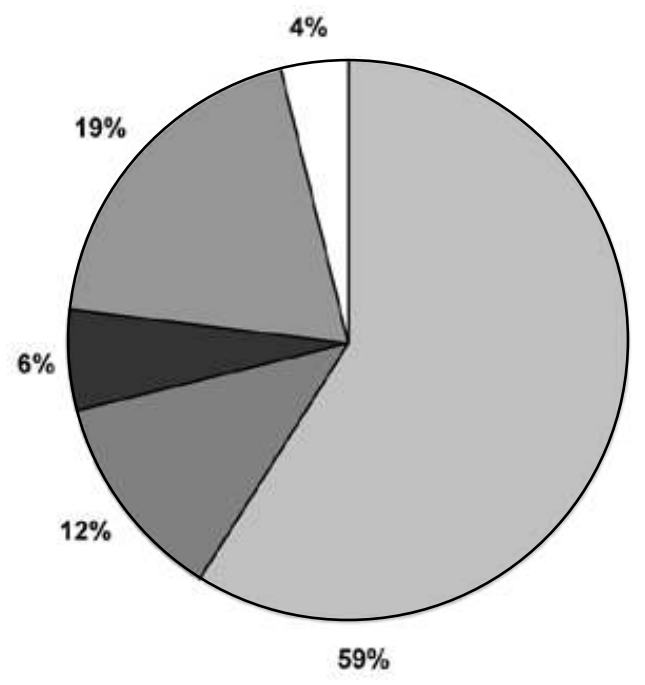

$\square$ Przemysł surowcowy

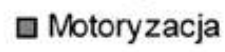

- Telekomunikacja

$\square$ Elektronika

$\square$ Handel

Źródło: opracowanie własne.

Ryc. 4. Największe aktywa wśród światowych korporacji transnarodowych posiadają według uczniów II LO w Zabrzu przedsiębiorstwa branży (najczęściej zaznaczane na miejscach 1-3)

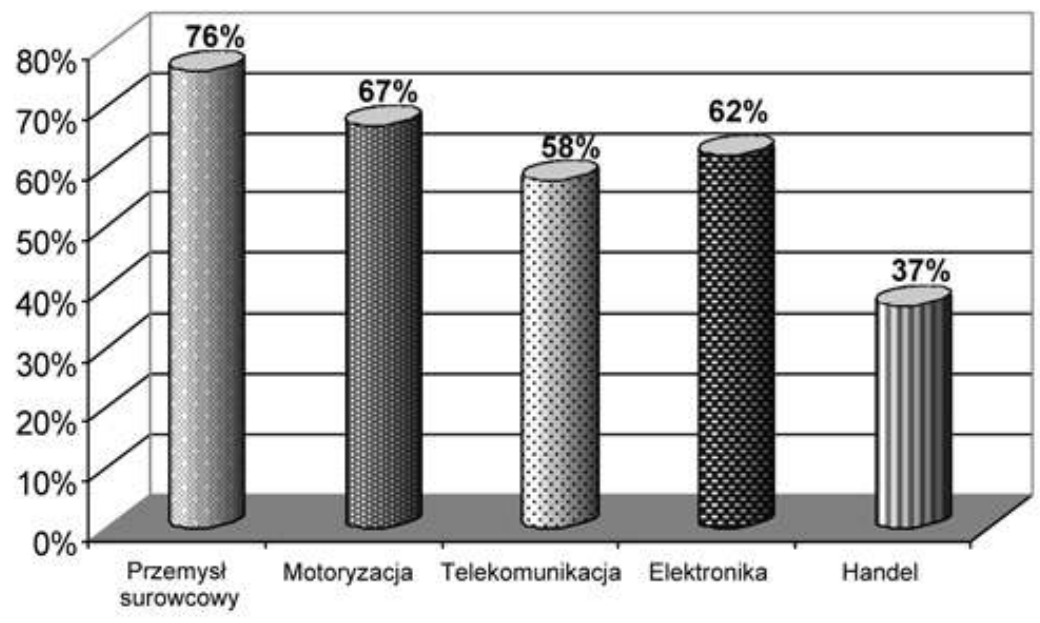

Źródło: opracowanie własne. 
Podsumowując te odpowiedzi, można stwierdzić, że poglądy młodzieży w dużym stopniu są zbieżne z publikowanymi rankingami największych korporacji transnarodowych.

Globalizacja, jak podkreślają wszyscy, jest procesem nieodwracalnym. Ma zwolenników i przeciwników. Ważne jest, żeby zdawać sobie sprawę z szans i zagrożeń, które stwarza. Najważniejsze pozytywne i negatywne skutki globalizacji uczniowie mogli wybrać w kolejnych pytaniach ankiety. Skutki te rozpatrywali w kontekście wpływu na gospodarkę Polski i codzienne życie młodego Polaka. Każdy ankietowany mógł zaznaczyć pięć z dwunastu pozytywnych i jedenastu negatywnych skutków globalizacji.

Zaznaczając najważniejsze pozytywne skutki globalizacji dla gospodarki Polski, uczniowie najczęściej wskazywali na postęp naukowo-techniczny (w tym np.: Internet, telefony komórkowe). Takiego wyboru dokonało aż 90\% z nich. Na kolejnych miejscach znalazły się: nowoczesność i udoskonalanie nowych produktów - 71\%, integracja gospodarcza - 60\%, zacieranie barier międzynarodowej wymiany handlowej oraz łatwość dostępu do informacji - po 59\% (ryc. 5). Analizując te wyniki, można stwierdzić, że uczniowie dokonali dość trafnych wyborów. Możemy się ewentualnie zastanawiać nad ustaloną przez nich kolejnością, na przykład, czy postęp naukowo-techniczny jest ważniejszy dla naszej gospodarki od integracji gospodarczej związanej z członkowstwem w Unii Europejskiej.

Ryc. 5. Pozytywne skutki globalizacji najważniejsze dla gospodarki kraju - według uczniów II LO w Zabrzu (zaznacz maksymalnie pięć najważniejszych według Ciebie odpowiedzi)

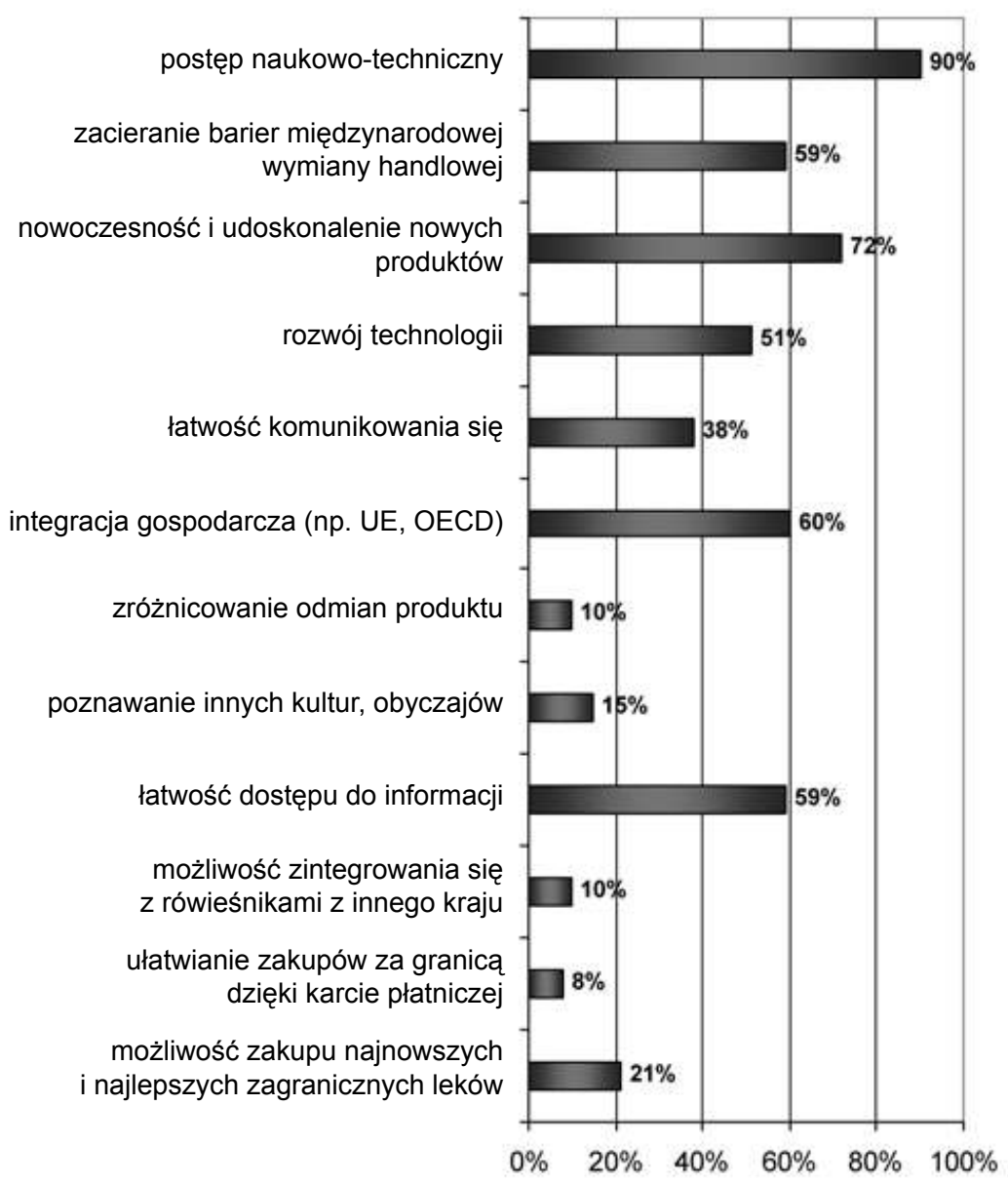

Źródło: opracowanie własne. 
Dla młodych Polaków, zdaniem uczniów II LO w Zabrzu, najważniejsze z pozytywnych skutków globalizacji są: postęp naukowo-techniczny - 83\%, łatwość komunikowania się - 74\%, rozwój technologii (np. sprzęt komputerowy) - 55\%, łatwość dostępu do informacji - 53\% i poznawanie innych kultur, obyczajów - 47\% (ryc. 6). W porównaniu z wynikami z poprzedniego pytania zmieniły się trzy odpowiedzi. Na pierwszym miejscu ponownie uczniowie wybrali postęp naukowo-techniczny. Należy jednak podkreślić dużą liczbę wskazań na łatwość komunikowania się oraz fakt, że dla uczniów istotne jest także poznawanie innych kultur i obyczajów wynikające z chęci poznawania ludzi i świata.

Ryc. 6. Pozytywne skutki globalizacji najważniejsze dla młodych Polaków - według uczniów II LO w Zabrzu

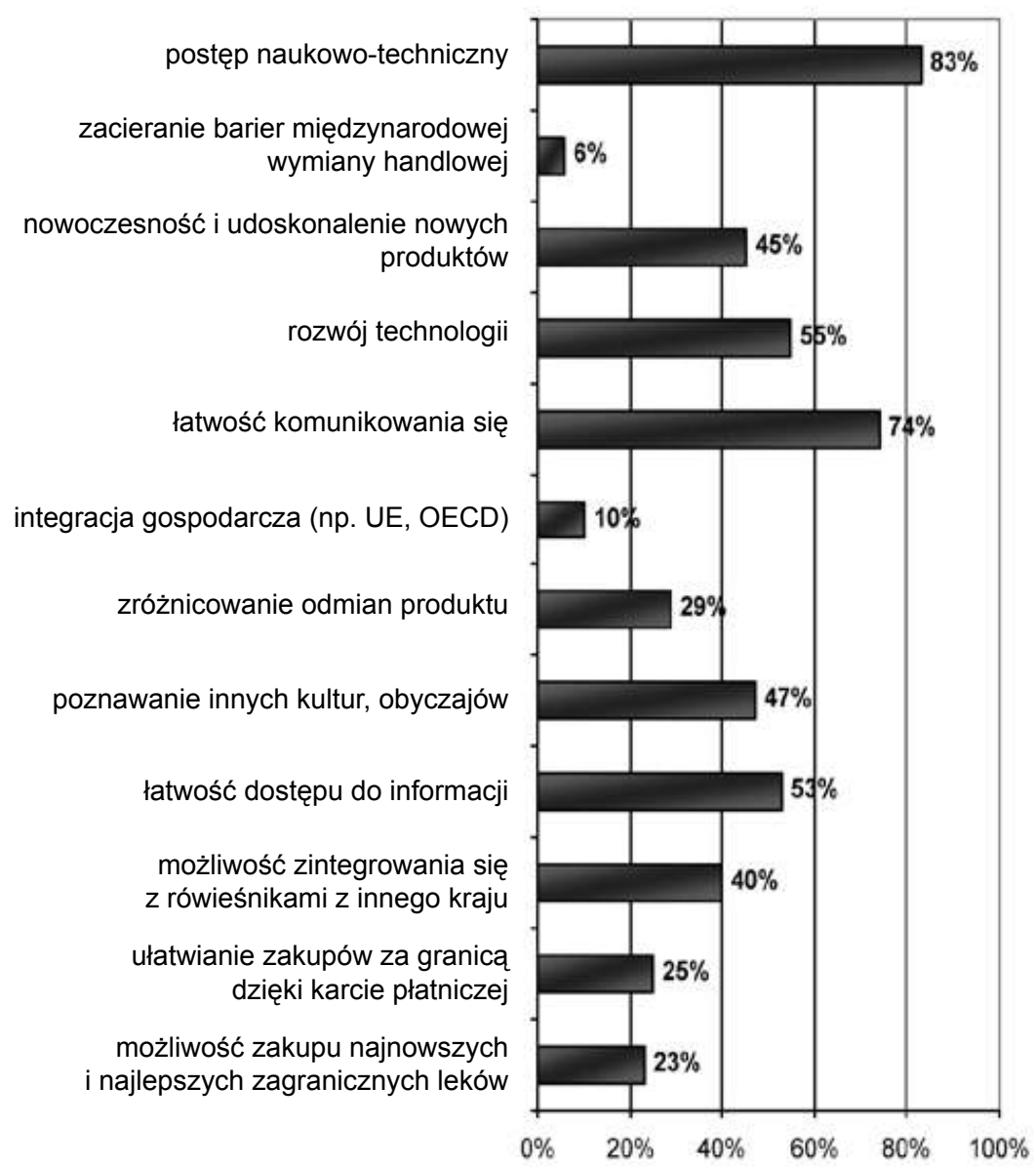

Źródło: opracowanie własne.

Dwa następne pytania, podobnie sformułowane jak poprzednie, dotyczyły negatywnych skutków globalizacji. Według uczniów największy wpływ na gospodarkę Polski mają: większa wrażliwość gospodarek narodowych na załamania na rynkach światowych - 59\%, wzrost zużycia energii i zanieczyszczenia środowiska poprzez przeniesienie produkcji do regionów o niższych standardach ekologicznych - 56\%, powstanie i rozrastanie się globalnych dysproporcji - 55\%, upadek drobnych przedsiębiorstw, które są mało konkurencyjne - 52\% (ryc. 7). Przyglądając się tym wynikom i porównując najwyższe wartości z dotyczącymi pozytywnych skutków globalizacji, widzimy, że młodzież miała większe problemy z jednoznacznym wskazaniem najważniejszych negatywnych skutków. Różnice pomiędzy przedstawionymi wyżej skutkami a pozostałymi są mniejsze niż w poprzednich pytaniach. 
Ryc. 7. Negatywne skutki globalizacji najważniejsze dla gospodarki kraju - według uczniów II LO w Zabrzu Źródło: opracowanie własne.

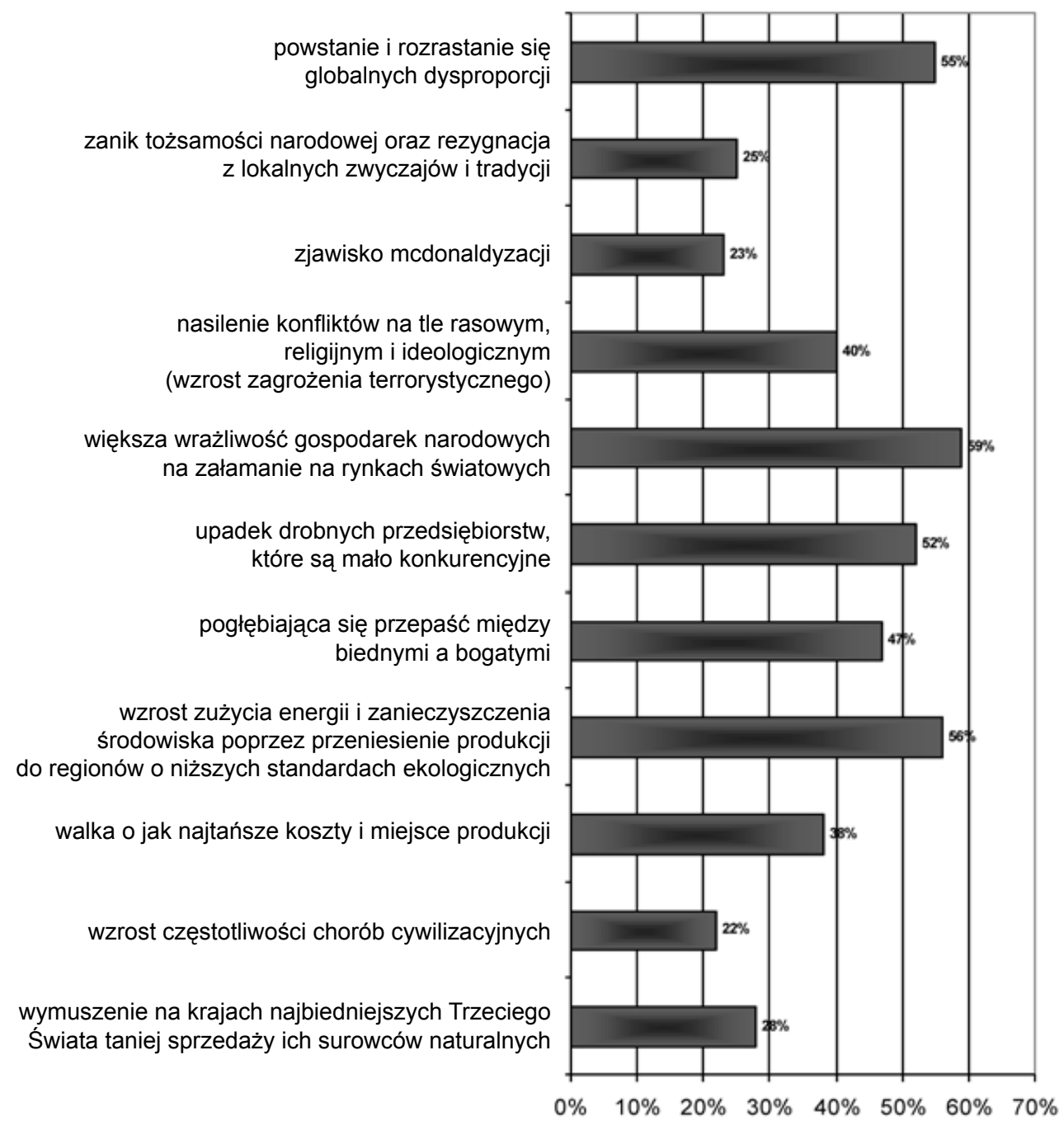

Odpowiedzi na pytanie o wpływ negatywnych skutków globalizacji na życie młodego Polaka, jeżeli chodzi o wartości procentowe, wyglądają podobnie. Uczniowie jednak wybierali najczęściej inne odpowiedzi niż w poprzednim pytaniu. Najczęściej zaznaczane odpowiedzi to: pogłębiająca się przepaść między biednymi a bogatymi - 58\%, wzrost częstotliwości występowania chorób cywilizacyjnych $-55 \%$, zanik tożsamości narodowej oraz rezygnacja z lokalnych zwyczajów i tradycji na rzecz powstającej kultury masowej - 53\% oraz wzrost zużycia energii i zanieczyszczenia środowiska poprzez przeniesienie produkcji do regionów o niższych standardach ekologicznych - 51\%; jest to jedyny negatywny skutek, który się powtórzył w odpowiedziach na dwa ostatnie pytania (ryc. 8).

Na podstawie przedstawionych wyników widzimy, że młodzież rozróżnia wagę i wpływ skutków globalizacji na sferę gospodarczą kraju od jej szans i zagrożeń dla społeczeństw i pojedynczego człowieka. Zdaje sobie też sprawę, że Polska nie jest wydzieloną wyspą na mapie świata i wszystkie dobrodziejstwa globalizacji jej dotyczą.

„Polska poprzez rosnące inwestycje zagraniczne oraz wymianę handlową włączana jest w procesy globalizacyjne. Dzieje się tak głównie dzięki postępowi technologicznemu, który ułatwia oraz powoduje obniżkę kosztów komunikacji, transportu, co w efekcie prowadzi do wzrostu 
międzynarodowego handlu oraz inwestycji zagranicznych. Za lokomotywy globalizacji uznaje się przede wszystkim nowoczesną komunikację rozumianą jako szybki i wydajny przepływ informacji. Za nimi idzie rozwinięta infrastruktura telekomunikacyjna, wymiana handlowa, wzrost gospodarczy, czy też wymiana turystyczna” (Stępkowicz 2007).

Ryc. 8. Negatywne skutki globalizacji najważniejsze dla młodych Polaków - według uczniów II LO w Zabrzu

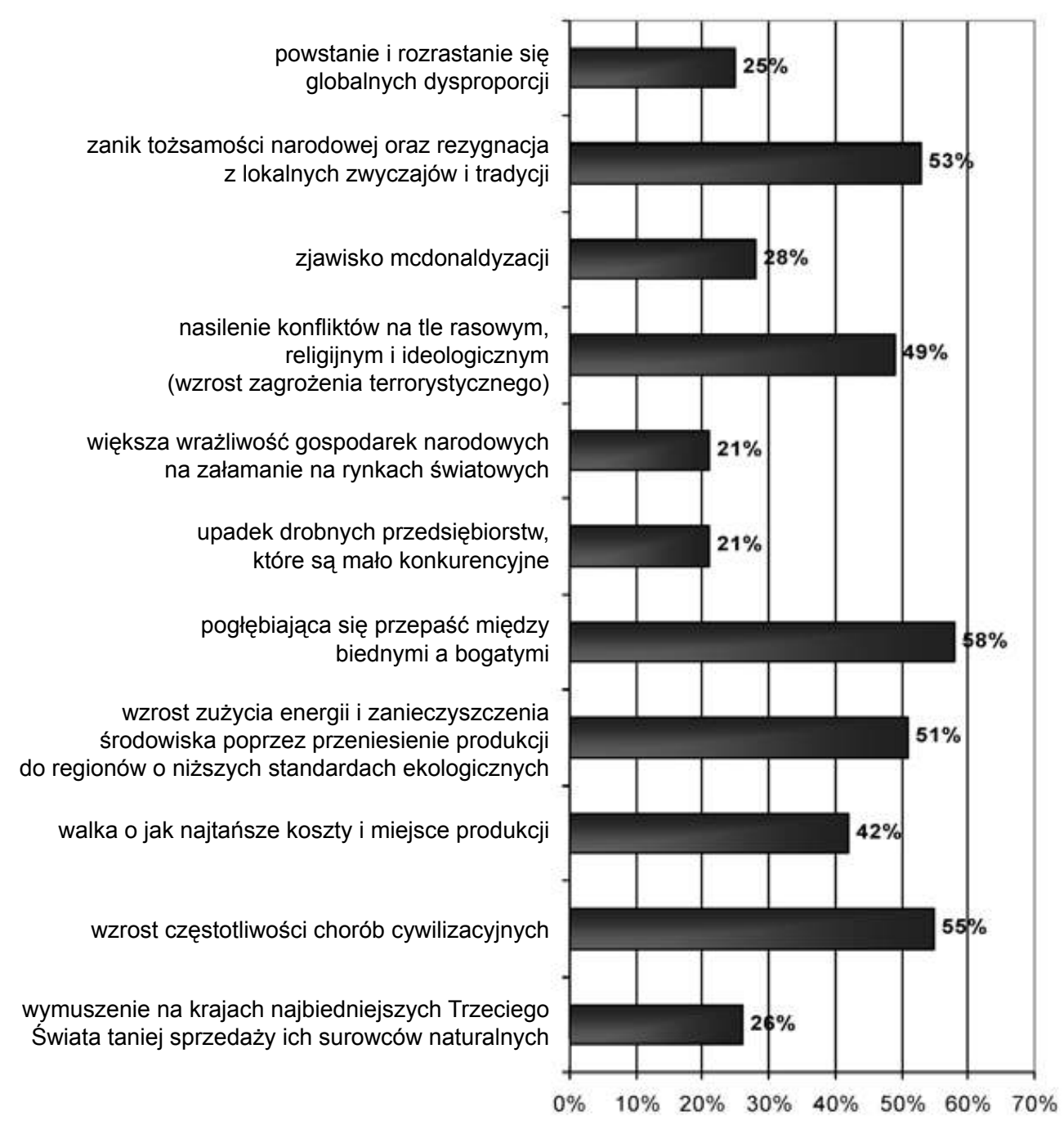

Źródło: opracowanie własne.

Uświadamianie młodzieży, że proces globalizacji wpływa na nasze otoczenie i życie jest jednym z celów prowadzonych przeze mnie zajęć poświęconych tematyce globalizacji. Chcę aby wiedzieli, że nie warto się teraz zastanawiać czy jest się „,za” czy „,przeciw” czemuś co jest powszechnie uważane za nieodwracalne. Może młodzi ludzie mogą pokierować tym procesem w taki sposób, aby wykorzystać globalizację do budowania równych szans na całym świecie, utrwalania wolności i pokoju i aby w przyszłości spełniła się tylko pierwsza część słów cytowanego już wcześniej Richarda Schechnera ,Zwolennicy globalizacji twierdzą, że przeważająca część ludzkości może osiągnąć wysoki poziom życia tylko poprzez systematyczną integrację, jakkolwiek bolesny byłby na krótką metę sam proces. Przeciwnicy globalizacji twierdzą, że usystematyzowanie oznacza, iż władza (i korzyści) pozostaną w rękach niewielu, powodując olbrzymie nierówności” (2007). 


\section{Literatura}

1. Kolka M.A., 2007, Korporacje transnarodowe-ich znaczenie w erze globalizacji, Wydawnictwo Instytutu Prognoz i Analiz, www.GlobalEconomy.pl.

2. Stępkowicz W., 2007, Globalizacja gospodarki - wybrane cechy procesu, Ministerstwo Gospodarki, Departament Analiz i Prognoz, Warszawa.

3. Schechner R., 2007, Performatyka: Wstęp, Kubikowski T. (przekł.), Instytut im. Jerzego Grotowskiego, Wrocław.

\section{The Process of Globalization. Evaluation of Positive and Negative Results of Globalization by the Polish Youth}

What is globalization? What does this term mean to young people? Is the dictionary definition of th is term meaningful to them; is schoolbook information on this issue thorough and precise? What are positive results of globalization and does the youth notice any negative results of globalization in Poland and worldwide? How can they support or counteract this process? Second and third grade secondary school students were asked these and similar questions connected with globalization. As a teacher of Entrepreneurship I have always emphasized my interest in opinions and attitudes of young people. Taking into consideration the young age of the surveyed, I decided that posing questions directly connected to this year conference and teachers' meetings title, that is entrepreneurship in the context of globalization, would be premature.

I would like to present the results of the survey conducted among the students of the school I work in and their opinions on the process as well as results of globalization in this year conference sessions. 